JURNAL PENDIDIKAN, p-ISSN 2715-095X, e-ISSN 2686-5041

Volume 30, No.3, Nopember 2021 (481-488)

Online: http://journal.univetbantara.ac.id/index.php/jp

\title{
Model Pembelajaran Kooperatif Tipe Numbered Head Together sebagai Upaya Meningkatkan Prestasi Belajar Prakarya
}

\author{
Sri Rejeki
}

SMP Negeri 5 Sukoharjo, E-mail: srirejeki237@gmail.com

Received: Juli 16, 2021

Accepted: Oktober 24, 2021

Online Published: Nopember 08, 2021

\begin{abstract}
Abstrak: Penelitian ini bertujuan untuk meningkatkan prestasi belajar prakarya melalui model pembelajaran kooperatif tipe NHT pada siswa kelas VII G SMP Negeri 5 Sukoharjo semester I tahun pelajaran 2017/2018. Penelitian ini adalah Penelitian Tindakan Kelas yang dilakukan di kelas VII G SMP Negeri 5 Sukoharjo semester I tahun pelajaran 2017/2018 yang berjumah 32 siswa. Teknik pengumpulan data yang digunakan adalah tes, observasi, dan dokumentasi. Tahap-tahap analisis data dalam penelitian ini adalah pengumpulan data, reduksi data, penyajian data, dan penarikan kesimpulan. Indikator keberhasilan adalah nilai rata-rata tes siswa sekurang-kurangnya 80,0 dan banyak siswa dengan nilai di atas kriteria ketuntasan minimal (KKM) yaitu 70,0 mencapai $\geq 85 \%$. Berdasarkan penelitian yang telah dilakukan, dapat disimpulkan bahwa penerapan model pembelajaran kooperatif tipe NHT dapat meningkatkan prestasi belajar bahasa prakarya siswa kelas VII G SMP Negeri 5 Sukoharjo. Sebelum tindakan/ prasiklus, prestasi belajar siswa yang mencapai KKM 15 siswaatau 46,9\%, pada siklus I, 23 siawa atau $71,9 \%$ dan pada siklus II, 30 siswa atau $93,75 \%$. Nilai rata-rata kelas sebelum tindakan/prasiklus sebesar 68,5 setelah tindakan siklus I sebesar 71,9 dan setelah tindakan siklus II sebesar 82,1.
\end{abstract}

Kata-kata Kunci: Model pembelajarankooperatiftipe NHT, prestasibelajarprakarya.

\section{Numbered Head Together Cooperative Learning Model as an Effort to Improve Craft Learning Achievement}

\author{
Sri Rejeki \\ SMP Negeri 5 Sukoharjo,E-mail: srirejeki237@gmail.com
}

\begin{abstract}
This study aims to improve learning achievement of craft subjects through cooperative learning model type NHT in students of class VII G SMP Negeri 5 Sukoharjo first semester academic year 2017/2018. This research is a Classroom Action Research conducted in class VII G SMP Negeri 5 Sukoharjo first semester of academic year 2017/ 2018 with 32 students. Data collection techniques used are tests, observations, and documentation. The stages of data analysis in this study are data collection, data reduction, data presentation, and conclusion. The success indicator is the average score of the student's test at least 80.0 and many students with a value above the minimum mastery criteria (KKM) of 70.0 reach $\geq$ 85\%.Based on the research that has been done, it can be concluded that the application of cooperative learning model type NHT can improve learning achievement of craft subjects student of class VII G SMP Negeri 5 Sukoharjo. Before the action / pre cycle, student learning outcomes reaching KKM 15 students or 46,9\%, in cycle I, 23 students or $71,9 \%$ and in cycle II, 30 students or $93,75 \%$. The average value of the class before the action / pre cycle was 68.5 after the first cycle action was 76,7 and after the second cycle action was 82.1.
\end{abstract}

Keywords: Cooperative learning model type NHT, learning achievement of craft subjects. 


\section{Pendahuluan}

Pembelajaran prakarya dimaksudkan dapat membangun apresiasi dan kreativitas siswa serta menumbuhkembangkan daya pikir imaginatif yang serba bisa. Daya pikir imaginatif dapat diraih apabila seorang anak berada dalam ruang lingkup pendidikan yang berorientasi pada pengembangan aktualisasi dan bimbingan yang mengarah pada polapikir yang berkembang. Dalam pembelajaran prakarya, kreativitas sangat diperlukan, karena pada dasarnya kreativitas merupakan faktor penunjang tercapainya keberhasilan dalam belajar segala bentuk seni, budaya serta keterampilan. Hal ini dapat dilakukan dengan berbagai pendekatan seperti Pendekatan Konstruktivistik, dimana seorang anak/ siswa dituntut untuk mencari sesuatu hal dengan kecerdasan berpikirnya melalui informasi secara mandiri, sehingga pada akhirnya anak mampu mencari dan menemukan suatu kreativitas melalui informasi serta pengetahuan yang telah didapatnya. Adapun pengertian kreativitas menurut John Adair adalah dayapikir dan semangat yang memungkinkan seseorang untuk mengadakan sesuatu yang memiliki kegunaan, tatanan, keindahan, atau arti penting dari sesuatu yang kelihatannya tidak ada. Sedangkan menurut Conny R. Semiawan, kreativitas merupakan kemampuan untuk melakukan gagasan baru dan menerapkannya dalam pemecahan masalah. Kreativitas itu sendiri memiliki 2 komponen yaitu Aptitude (kecakapan) dan Non Aptitude (bukankecakapan).

Kreativitas bisa ditumbuhkan dalam proses pembelajaran. Dimana siswalah yang menjadi subyek dalam pembelajaran. Dialah pelaku kegiatan belajar. Agar siswa berperan sebagai pelaku dalam kegiatan belajar maka guru hendaknya merencanakan pembelajaran yang menarik. Sehingga kegiatan pembelajaran dapat diciptakan di sekolah dan akan menjadikan suasana pembelajaran yang tidak membosankan sehingga peserta didik mengikuti pembelajaran dengan bertanya, mempertanyakan, dan mengemukakan gagasan.

Pada umumnya guru masih menggunakan model pembelajaran konvensional sehingga pembelajaran menjadi satu arah. Hal itu menyebabkan siswa cenderung pasif dan kurang tertarik dengan materi yang diberikan sehingga banyak siswa yang tidak memperhatikan materi pembelajaran. Sebagian besar siswa lebih banyak mendengarkan, mencatat dan kurang aktif dalam kegiatan pembelajaran. Suasana belajar seperti inilah yang terjadi pada siswa kelas VII G SMP Negeri 5 Sukoharjo. Selama proses pembelajaran prakarya berlangsung, siswa Kelas VII G mengikuti pelajaran dengan baik, tetapi siswa kurang merespon materi yang diberikan oleh guru. Kondisi seperti ini berdampak pada rendahnya prestasi belajar siswa pada aspek pengetahuan. Sebagian besar siswa mengalami kesulitan belajar Budidaya Tanaman Sayuran. Karena materi ini memang cukup sulit dan siswa cenderung malu bertanya kepada guru jika mengalami kesulitan dalam memahami atau menyelesaikan soal yang diberikan, akibatnya prestasi belajar siswa pada materi tersebut belum maksimal. Randahnya keaktifan para siswa dalam belajar menjadi petunjuk bahwa siswa mengalami kesulitan belajar. Sehingga perlu adanya variasi pembelajaran agar siswa tertarik dan aktif dalam proses belajar mengajar (Suwarto, 2013, 2017).

Dari hasil tes materi Budidaya Tanaman Sayuran, siswa kelas VII G Semester I SMP Negeri 5 Sukoharjo Tahun Pelajaran 2017/2018 prestasi belajar untuk mata pelajaran prakarya masih rendah. Diperoleh nilai rata-rata kelas 68,5, sedangkan KKM (Kriteria Ketuntasan Minimun) adalah 70 dengan jumlah siswa yang tuntas belajar sebanyak 15 siswa (46,9\%). Terdapat beberapa model pembelajaran kooperatif yang dapat diterapkan, yaitu antara lain STAD (Student Team-Archievement Divisions), jigsaw, TAI (Team 
Accelerated Instruction), TGT (Teams-Games-Tournaments), dan NHT (Numbered Heads Together). Pada penelitian ini akan dicoba pembelajaran kooperatif tipe NHT (Numbered Heads Together). Teknik ini memberikan kesempatan kepada siswa untuk saling membagikan ide-ide dan mempertimbangkan jawaban yang paling tepat, selain itu mendorong siswa untuk meningkatkan semangat kerjasama dan daya serap materi yang diberikan guru. Penggunaan model pembelajaran kooperatif NHT diharapkan menjadi sarana belajar yang menarik dan menyenangkan, sehingga akan meningkatkan prestasi belajar siswa. Namun, apakah benar tidaknya pembelajaran kooperatif tipe NHT dapat meningkatkan prestasi belajar siswa pada materi Budidaya Tanaman Sayuran, maka perlu dilakukan penelitian. Belajar menurut Sugihartono, dkk (2007) merupakan suatu proses perubahan tingkah laku sebagai hasil interaksi individu dengan lingkungannya dalam memenuhi kebutuhan hidupnya. Menurut Sanjaya (2008) belajar adalah proses mental yang terjadi dalam diri seseorang, sehingga menyebabkan munculnya perubahan tingkah laku. Aktivitas mental itu terjadi karena adanya interaksi individu dengan lingkungan yang disadari. Belajar merupakan proses yang berlangsung terus menerus sepanjang hidup, baik melalui pendidikan formal, informal maupun melalui pengalaman hidup sehari-hari (Rahmayanti, 2016: 212). Menurut Dimyati dan Mudjiono (2009) belajar adalah proses melibatkan manusia secara orang per orang sebagai satu kesatuan organisme sehingga terjadi perubahan pada pengetahuan, keterampilan, dan sikap. Sedangkan menurut Slameto dalam Djamarah (2008), belajar adalah suatu proses usaha yang dilakukan individu untuk memperoleh suatu perubahan tingkah laku yang baru secara keseluruhan, sebagai hasil pengalaman individu itu sendiri dalam interaksi dengan lingkungannya. Sunhaji (2014: 33) beranggapan bahwa belajar adalah proses berubahnya tingkah laku (change in behavior) yang disebabkan karena pengalaman dan latihan. Pengalaman dan latihan tersebut merupakan aktivitas guru sebagai pembelajar dan aktivitas siswa/peserta didik sebagai pembelajar. Perubahan peri laku tersebut dapat berupa mental maupun fisik. Dasopang (2017: 337) beranggapan bahwa belajar adalah proses perubahan tingkah laku dan perubahan pemahaman, yang pada mulanya seorang anak tidak dibekali dengan potensi fitrah, kemudian dengan terjadinya proses belajar maka seorang anak berubah tingkah laku dan pemahamannya semakin bertambah. Merangkum dari pendapat-pendapat di atas, maka belajar merupakan suatu proses memperoleh pengetahuan dan pengalaman dalam wujud perubahan tingkah laku karena adanya interaksi individu dengan lingkungannya.

Prestasi adalah hasil dari suatu kegiatan yang telah dikerjakan, diciptakan baik secara individual maupunkelompok (Hamdani, 2011). Sedangkan menurut Purwodarminto (dalam Hamdani, 2011) menyatakan bahwa prestasi belajar adalah hasil yang dicapai sebaik-baiknya menurut kemampuan anak pada waktu tertentu terhadap hal-hal yang dikerjakan atau dilakukan. Selain itu, Winkel (dalam Hamdani, 2011) mengemukakan bahwa prestasi belajar adalah merupakan bukti yang telah dicapai oleh seseorang. Prestasi belajar menurut Kholis (2017: 76) merupakan suatu dasar dalam menentukan tingkat keberhasilan siswa yang ditandai dengan perubahan diri siswa terhadap penguasaan sejumlah bahan yang diberikan dalam proses belajar mengajar yang mencakup aspek kognitif, afektif dan psikomotorik. Menurut Hamdani (2011)"Prestasi belajar adalah hasil dari pengukuran terhadap siswa yang meliputi faktor kognitif, afektif dan psikomotorik setelah mengikuti proses pembelajaran yang diukur dengan menggunakan instrumen tes atau instrumen yang relevan". Jadi prestasi belajar adalah hasil pengukuran dari penilaian usaha belajar yang dinyatakan dalam bentuk simbol, huruf maupun kalimat yang 
menceritakan hasil yang sudah dicapai oleh setiap anak pada periode tertentu. Menurut Huda (2011), penerapan pembelajaran kooperatiftipe NHT akan memberikan kesempatan kepada siswa untuk saling membagikan ide-ide dan mempertimbangkan jawaban yang paling tepat, meningkatkan semangat kerjasama siswa dan dapat digunakan untuk semua mata pelajaran dan tingkat kelas.Barutu (2014: 144) beranggapan bahwa NHT merupakan suatu model pembelajaran yang melibatkan siswa secara aktif dalam menelaah materi yang tercakup dalam suatu pelajaran. Pada pembelajaran ini setiap siswa akan diberi nomor yang berbeda untuk setiap kelompoknya. Adapun prosedur dalam metode pembelajaran kooperatif tipe NHT, yaitu: (1) Siswa dibagi dalam kelompok-kelompok. Masing-masing siswa dalam kelompok diberi nomor; (2) Guru memberikan tugas/pertanyaan dan masingmasing kelompok mengerjakannya; (3) Kelompok berdiskusi untuk menemukan jawaban yang dianggap paling benar dan memastikan semua anggota kelompok mengetahui jawaban tersebut; (4) Guru memanggil salah satu nomor. Siswa dengan nomor yang dipanggil mempresentasikan jawaban hasil diskusi kelompoknya. Tujuan penelitian ini adalah untuk meningkatkan prestasi belajar prakarya melalui pembelajaran kooperatif tipe NHT pada siswa SMP Negeri 5 Sukoharjo kelas VII G Semester I tahun pelajaran 2017/ 2018.

\section{Metode Penelitian}

Penelitian ini adalah Penelitian Tindakan Kelas. Penelitian tindakan kelas merupakan suatu pencermatan terhadap kegiatan yang sengaja dimunculkan, dan terjadi dalam sebuah kelas (Arikunto, 2010: 130). Penelitian ini dilaksanakan di SMP Negeri 5 Sukoharjo. Tahap-tahap pelaksanaan kegiatan dilakukan selama kurang lebih enam bulan yaitu sejak bulan Juli sampai dengan Desember 2017. Peneliti sebagai guru SMP Negeri 5 Sukoharjo bertindak sebagai subjek yang melakukan tindakan kelas. Teman sejawat sesama guru mata pelajaran prakarya sebagai observer. Kepala Sekolah bertindak sebagai subjek yang membantu dalam perencanaan dan pengumpulan data. Subjek yang menerima tindakan adalah siswa kelas VII G SMP Negeri 5 Sukoharjo semester I tahun pelajaran 2017/ 2018 sebanyak 32 siswa. Adapun langkah-langkah penelitian untuk setiap siklus pembelajaran adalah sebagai berikut:

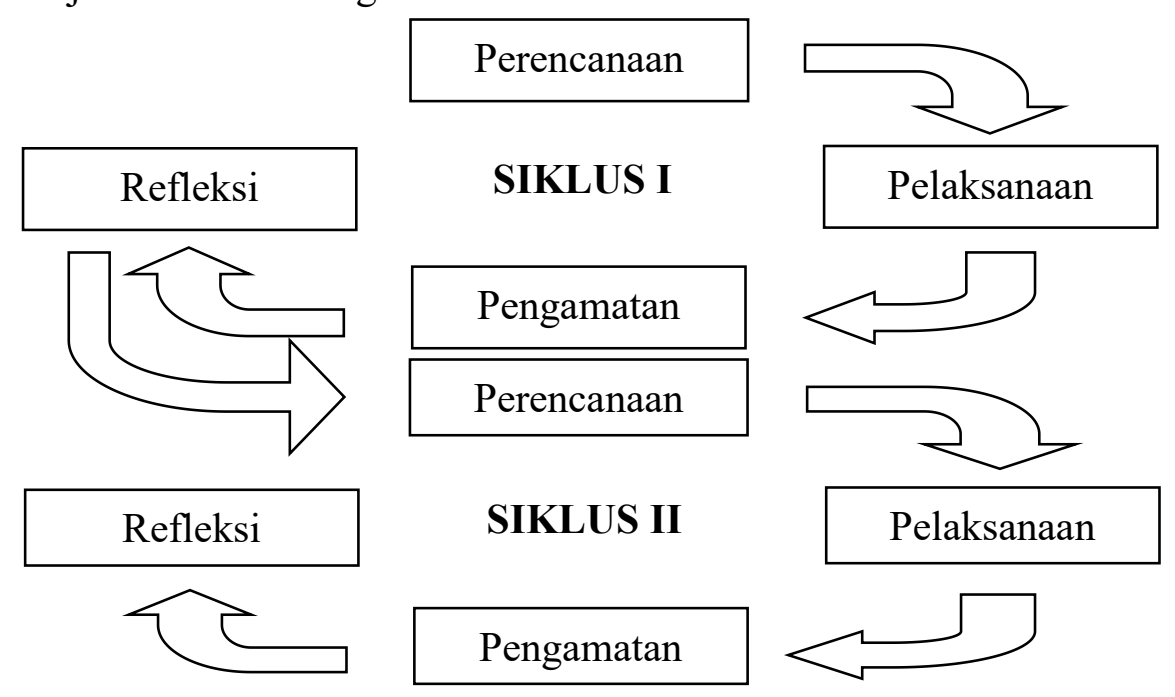

Gambar 1. SiklusPenelitian Tindakan (Arikunto, 2006) 
Teknik pengumpulan data yang digunakan adalah: tes, observasi dan dokumentasi. Tesadalah serentetan pertanyaan atau latihan serta alat lain yang digunakan untuk mengukur keterampilan, pengetahuan inteligensi, kemampuan atau bakat yang dimiliki oleh individu dan kelompok (Arikunto, 2010 : 193). Tes digunakan adalah jenis tes hasil (achievementtest)berupa kuis individu. Tes ini digunakan untuk mengukur pencapaian siswa setelah mempelajari materi. Hal ini dapat juga sebagai alat untuk mengetahui tingkat pemahaman siswa setelah mempelajari pokok bahasan Budidaya Tanaman Sayuran dengan menggunakan model pembelajaran kooperatif tipe NHT.

Kuis individu yang dimaksudkan ini adalah tes tertulis. Tes tertulis adalah suatu teknik penilaian yang menunutut jawaban secara tertulis, baik berupa pilihan atau isian. Tes yang jawabannya berupa pilihan meliputi pilihan ganda, benar salah dan menjodohkan, sedangkan tes yang jawabannya berupa isian berbentuk isian singkat atau uraian (Suprijono, 2013). Observasi atau pengamatan dilakukan guna memperoleh data yang akurat, dengan menggunakan lembar observasi. Lembar observasi digunakan untuk memonitor dan mengevaluasi setiap tindakan agar kegiatan observasi tidak terlepas dari konteks permasalahan dan tujuan penelitian. Observasi yang digunakan adalah observasi sistematis, yaitu observasi yang dilakukan oleh pengamat dengan menggunakan pedoman sebagai instrumen pengamatan dan observasi non-sistematis yang dilakukan dengan tidak menggunakan instrumen pengamatan. Dokumentasi diperoleh dari hasil kuis siswa, lembar observasi, lembar wawancara, catatan lapangan, daftar siswa, dan foto-foto selama proses kegiatan belajar mengajar. Dokumentasi ini dimaksudkan adalah sebagai bukti-bukti konkret dari penelitian tindakan kelas tersebut.

Instrumen yang digunakan dalam penelitian berupa tes, lembar observasi dan lembar dokumentasi. Tes berbentuk tes tertulis maupun lisan yang dilakukan dalam post test dan kuis individu. Tes ini digunakan untuk mengetahui sejauh mana peningkatan prestasi belajar Budidaya Tanaman Sayuran siswa dengan penerapan model pembelajaran kooperatif tipe NHT. Lembar Observasi, digunakan lembar observasi prestasi belajar siswa dan lembar observasi pelaksanaan pembelajaran kooperatif. Lembar observasi digunakan pada setiap pembelajaran sehingga kegiatan observasi tidak terlepas dari konteks permasalahan dan tujuan penelitian, untuk lembar prestasi belajar siswa digunakan pada saat siswa dapat menyelesaikan permasalahan dengan kegiatan belajar mengajar dan sedangkan lembar observasi pelaksanaan kegiatan belajar mengajar dengan model pembelajaran Kooperatif Tipe NHT digunakan sebagai pedoman peneliti dalam melakukan observasi pelaksanaan kegiatan belajar mengajar dengan menggunakan model pembelajaran kooperatif tipe NHT. Lembar dokumentasi ini bertujuan untuk mengetahui data siswa selama kegiatan penelitian berlangsung. Lembar dokumentasi ini berupa, fotofoto kegiatan pembelajaran, daftar hadir kegiatan pembelajaran, daftar hadir, daftar nilai, kartu pasangan soal/jawaban dan sebagainya.

Indikator keberhasilan kinerja dalam penelitian ini adalah meningkatnya prestasi belajar prakarya materi Budidaya Tanaman Sayuran siswa, yang ditunjukkan dengan meningkatnya nilai rata-rata tessiswasekurang-kurangnya 80,0 dan banyak siswa dengan nilai di atas kriteria ketuntasan minimal $(\mathrm{KKM})$ yaitu $\geq 70,0$ mencapai $\geq 85 \%$.

\section{Hasil Penelitian}

Deskripsi data hasil penelitian yang telah dilakukan di kelas VII G SMP Negeri 5 
Sukoharjo adalah sebagai berikut. Berdasarkan observasi awal di kelas VIIG mata pelajaran prakarya dengan materi Budidaya Tanaman Sayuran diperoleh data, dari 32 siswa yang mencapai nilai KKM sebanyak 15 siswa (46,9\%), dengan nilai rata-rata kelas sebesar 68,5. Penelitian ini dilakukan dengan indikator kinerja nilai rata-rata tes siswa sekurangkurangnya 80,0 dan banyak siswa dengan nilai di atas $\mathrm{KKM}$ yaitu $\geq 70,0$ mencapai $\geq 85 \%$.

\section{Pembahasan}

Hasil observasi awal menunjukkan bahwa guru yang mendominasi kegiatan pembelajaran dan siswa cenderung tidak aktif. Salah satu solusi yang dikembangkan adalah penggunaan model pembelajaran yang baru yaitu dengan Model Pembelajaran Kooperatif Tipe NHT. Dengan penggunaan model pembelajaran tersebut diharapkan akan menciptakan suasana belajar yang berbeda, bervariasi dan menyenangkan sehingga dapat menarik perhatian siswa, meningkatkan keaktifan siswa yang muara akhirnya meningkatkan prestasi belajar siswa.

Berdasarkan hasil evaluasi pada siklus I menunjukkan adanya peningkatan prestasi belajar siswa. Prestasi belajar siswa sebanyak 23 mencapai nilai KKM atau 71,9\%, rata-rata kelas naik menjadi 76,7. Berdasarkan pengamatan tersebut dapat diketahui bahwa proses pembelajaran pada siklus pertama belum berhasil maksimal dan belum mencapai indikator kinerja yang diharapkan. Peningkatan hasil, jika dibandingkan hasil prasiklus yang mencapai KKM sebanyak 15 siswa atau 46,9\% setelas diberi tindakan penerapan siklus I, siswa yang mencapai KKM sebanyak 23 siswa atau 71,92\%.

Tabel 1.PerkembanganSiswa yang Mencapai KKM Prasiklus ke Siklus I

\begin{tabular}{rrr}
\hline HasilSiswa & Prasiklus & \multicolumn{1}{c}{ Siklus I } \\
\hline Siswamencapai KKM & 15 & 23
\end{tabular}

Dari tabel di atas dapat disimpulkan bahwa prestasi relajar prakarya materi Budidaya Tanaman Saturan siswa dengan menerapkan model pembelajaran kooperatif tipe NHT, pada pelaksanaan tindakan siklus I mengalami peningkatan. Siswa yang mencapai KKM Sebelum dilakukan tindakan atau prasiklus 15 siswa, setelah tindakan siklus I sebanyak 23 siswa sehingga meningkat 8 siswa.

Setelah dievaluasi bersama dari pelaksanaan tindakan pada siklus I yang digunakan sebagai bagian pertimbangan perencanaan pembelajaran siklus berikutnya, dengan perencanaan perbaikan untuk mengatasi kekurangan dan kesalahan yang dilakukan pada siklus I. Berdasarkan pembelajaran secara keseluruhan pada tindakan kelas siklus II menunjukan adanya peningkatan yang signifikan. Prestasi relajar siswa sebanyak 30 siswa $(93,75 \%)$ mencapai KKM. Sehingga rata-rata nilaikelas VII G naik menjadi 82,1.

Tabel 2. PerkembanganSiswa yang Mencapai KKM Siklus I keSiklus II

\begin{tabular}{ccc}
\hline Hasil Siswa & Siklus I & Siklus II \\
\hline Siswa mencapai KKM & 23 & 30
\end{tabular}

Dari tabel di atas dapat disimpulkan bahwa prestasi relajar Budidaya Tanaman Saturan siswa dengan menerapkan model pembelajaran kooperatif tipe NHT, pada pelaksanaan tindakan siklus II mengalami peningkatan. Siswa yang mencapai KKM pada saat dilakukan tindakan siklus I sebanyak 23 siswa, setelah tidakan siklus II sebanyak 30 siswa sehingga meningkat 7 siswa. Berdasarkan hasil tersebut dapat diketahui bahwa proses pembelajaran sampai dengan pada siklus II berjalan dengan baik dan telah 
memenuhi indikator kinerja yang diharapkan. Pada siklus I dan II dengan penerapan tindakan menggunakan model pembelajaran kooperatif tipe NHT, sehingga siswa lebih antusias dengan perasaan senang dalam mengikuti kegiatan pembelajaran. Nilai rata-rata siswa Sejas sebelum diadakan penelitian ingá setelah diadakan penenelitian sampai dengan siklus II, dapat dilihat pada tabel berikut:

Tabel 3.Perkembangan Siswa Mencapai KKM Prasiklus, Siklus I dan Siklus II

\begin{tabular}{lccc}
\hline Hasil Siswa & Prasiklus & Siklus I & Siklus II \\
\hline Siswa mencapai KKM & 15 & 23 & 30
\end{tabular}

Dari tabel di atas dapat disimpulkan bahwa prestasi relajar materi Budidaya Tanaman Saturan siswa dengan menerapkan model pembelajaran kooperatif tipe NHT, di setiap pelaksanaan tindakan, baik siklus I dan siklus II mengalami peningkatan, yaitu: siswa yang mencapai KKM Sebelum dilakukan tindakan atau prasiklus 15 siswa, setelah tidakan siklus I sebanyak 23 siswa dan setelah tindakan siklus II sebanya 30 siswa, sehingga peningkatan kumulatif dari sebelum tindakan/prasiklus sampai dengan siklus II sebesar 10 siswa.

Tabel 4.Perkembangan Persentase Siswa Mencapai KKM Prasiklus, Siklus I dan Siklus II

\begin{tabular}{lccc}
\hline Hasil Siswa & Prasiklus & \multicolumn{1}{c}{ Siklus I } & \multicolumn{1}{c}{ Siklus II } \\
\hline Presentase Siswa & $46,9 \%$ & $71,9 \%$ & $93,75 \%$ \\
Mencapai KKM & & & \\
\hline
\end{tabular}

Dari tabel di atas dapat disimpulkan bahwa prestasi relajar materi Budidaya Tanaman Saturan siswa dengan menerapkan model pembelajaran kooperatif tipe NHT, di setiap pelaksanaan tindakan mengalami peningkatan, yaitu: presentase siswa yang mencapai KKM Sebelum dilakukan tindakan atau prasiklus $46,9 \%$, setelah tidakan siklus I sebanyak $71,9 \%$ dan setelah tindakan siklus II sebanyak $93,75 \%$.

Tabel 5. Perkembangan Nilai Rata-rata Kelas Prasiklus, Siklus I dan Siklus II

\begin{tabular}{rlll} 
Hasil Siswa & Prasiklus & Siklus I & Siklus II \\
\hline Nilai rata-rata & 68,5 & 76,7 & 82,1
\end{tabular}

Dari tabel di atas dapat disimpulkan bahwa prestasi relajar prakarya materi Budidaya Tanaman Saturan siswa dengan menerapkan model pembelajaran kooperatif tipe NHT, di setiap pelaksanaan tindakan mengalami peningkatan, yaitu: nilai rata-rata kelas sebelum dilakukan tindakan atau prasiklus adalah 68,5, setelah tidakan siklus I adalah 76,7 dan setelah tindakan siklus II adalah 82,1 sehingga dari kondisi awal sebelum tindakan/prasiklus sampai dengan tidakan pada siklus II terjadi peningkatan. Dari uraian di atas dapat disimpulkan bahwa model pembelajaran kooperatif tipe NHT dapat meningkatkan prestasi relajar prakarya materi Budidaya Tanaman Saturan siswa kelas VII G SMP Negeri 5 Sukoharjo semester I tahun pelajaran 2017/2018.

\section{Simpulan dan Saran}

Berdasarkan hasil penelitian dapat disimpulkan, dengan penerapan model pembelajaran kooperatif tipe NHT dapat meningkatkan prestasi relajar prakarya pada siswa kelas VIIG SMP Negeri 5 Sukoharjo semester I tahun pelajaran 2017/ 2018. Penelitian 
Tindakan Kelas (PTK) yang dilaksanakan di SMP Negeri 5 Sukoharjo ini sudah berjalan dengan cukup baik dan hasil yang baik pula. Namun, masih banyak hal yang perlu diperbaiki. Oleh karena itu, peneliti memberikan beberapa saran. (1) Siswa diharapkan dapat lebih meningkatkan kemampuan diri melalui peranaktifnya dalam mengikuti kegiatan relajar mengajar. Peran aktif tersebut meliputi peran aktif dalam bertanya, mengemukakan pendapat maupun mempresentasikan gagasannya. (2) Guru prakarya hendaknya dapat menumbuhkembangkan kreativitas dalam menjalankan profesinya sebagai fasilitator dan motivator dalam menyampaikan pembelajaran secara kreaktif dan inovatif pada siswa dalam penyampaian materi, sehingga siswa dapat menerima dan memahami materi yang diajarkan dengan baik. (3) PTK ini diharapkan akan membawa dampak positif terhadap perkembangan sekolah yang nampak pada peningkatan prestasi belajar siswa sehingga dapat meningkatkan prestasi dan kualitas sekolah.

\section{Daftar Rujukan}

Arikunto, A. (2006). ProsedurPenelitianSuatuPendekatanPraktik. Jakarta: RinekaCipta.

Barutu, Anwar dkk. (2017). Penerapan Model Pembelajaran Kooperatif Tipe Numbered Head Together (NHT) dengan Media Kartu Soal untuk Meningkatkan Hasil Belajar Matematika Siswa SMP. Jurnal Penelitian Pembelajaran Matematika Sekolah (JP2MS), Volume 1(2).

Dasopang, Aprida Pane Muhammad Darwis. (2017). Belajar dan Pembelajaran. Jurnal Kajian Ilmu-ilmu Keislaman, Volume 03(2).

Dimyati dan Mudjiono. (2009). Belajar dan Pembelajaran. Jakarta: RinekaCipta.

Djamarah, S. B. (2008). PsikologiBelajar. Jakarta: RinekaCipta.

Hamdani. (2011). Strategi BelajarMengajar. Bandung: Pustaka Setia.

Huda, M. (2011). Coopertive Learning Metode, Teknik, Struktur dan Model Penerapan. Yogyakarta: Putaka Pelajar.

Kholis, Nur. (2017). Penggunaan Model Pembelajaran Numbered Head Together untuk Meningkatkan Hasil Belajar Siswa. Jurnal Kajian Ilmu Pendidikan, Volume 2(1), 69-88.

Rahmayanti, Vina. (2016). Pengaruh Minat Belajar Siswa dan Persepsi Atas Upaya Guru dalam Memotivasi Belajar Siswa terhadap Prestasi Belajar Bahasa Indonesia Siswa SMP di Depok. Jurnal SAP, Volume 1(2).

Sanjaya, W. (2008). Stretegi Pembelajaran Berorientasi Standar Proses Pendidikan. Jakarta: Kencana.

Sugihartono, dkk. (2007). Psikologi Pendidikan. Yogyakarta: UNY Press.

Sunhaji. (2014). Konsep Manajemen Kelas dan Implikasinya dalam Pembelajaran. Jurnal Kependidikan, Volume 2(2).

Suprijono, Agus. (2009). Cooperative Learning Teori dan Aplikasi Paikem. Yogyakarta: Pustaka Pelajar.

Suwarto, D. (2013). Pengembangan Tes Diagnostik Dalam Pembelajaran. Yogyakarta: Pustaka Pelajar.

Suwarto, S. (2017). Pengembangan tes ilmu pengetahuan alam terkomputerisasi. Jurnal Penelitian dan Evaluasi Pendidikan, 21(2), 153-161. 